\title{
LIFE VALUES OF PERSONS IN CROSS-CULTURAL (ARAB - RUSSIAN) AND MONOCULTURAL MARRIAGES AND THEIR REPRESENTATION IN FAMILY SPHERE
}

\author{
Elena Y. Chebotareva ${ }^{1,2,3}$, Hasan M.A. Jaber ${ }^{1}$ \\ ${ }^{1}$ Peoples' Friendship University of Russia (RUDN University) \\ Miklukho-Maklaya str., 6, Moscow, Russia, 117198 \\ ${ }^{2}$ Moscow State University of Psychology and Education \\ Sretenka str., 29, Moscow, Russia, 127051 \\ ${ }^{3}$ National Research University "Higher School of Economics" \\ Myasnitskaya str., 20, Moscow, Russia, 101000
}

\begin{abstract}
The paper presents the results of the empirical study, which has been conducted with the aim to analyze the differences in life and family values and their interactions between the spouses from cross-cultural and monocultural couples. The sample of the study consists of 330 persons, including 85 cross-cultural Arab - Russian couples (170 persons), living in Russia, and 80 monocultural couples (160 persons).

The main methods were S. Schwartz' "Value Survey", "Test of Attitudes to Family Life" by Yu. Alyoshina, L. Gozman, \& E. Dubovskaya, «Marital Role Expectations and Aspirations" by A.N. Volkova, "Marital Satisfaction Test” by V. Stolin, T. Romanova, \& G. Butenko.

It was revealed that the persons from cross-cultural and monocultural marriages have different life and family values hierarchies, besides, they realize their life values in family life differently. In crosscultural marriages the spouses see the opportunities for their normative life goals realizing in the family, especially in its psychotherapeutic and parental spheres, as well as in social activity outside the family. But in their real day-to-day activities, they do not always manage to realize their life goals in the family sphere, probably because of the difficulties in interacting with their social environment, which can come from the fact that their families are more enclosed, which in turn leads to a decrease of marital satisfaction. In the cross-cultural spouses' representations, the collectivist values are more related to family functioning, but individualistic values such as hedonism and power are perceived as incompatible with the successful functioning of the family.
\end{abstract}

Key words: cross-cultural marriage, intercultural marriage, life values, family values, attitudes to family life, family functions, family roles, expectations and aspirations in marriage, marital satisfaction

\section{Theoretical background}

Cross-cultural families have become an integral part of the society, their number is steadily growing in almost any country. The recent years' migration outburst made it particularly relevant to study the processes of migrants' integration into the host community, including the psychological characteristics of cross-cultural families and their impact on the spouses' identity. Many researchers of the problem note that the 
religious identity is the major barrier for interethnic marriage. Therefore, $\mathrm{McClendon}$ (2016) states that interfaith marriage has become more common, however religion still remains one of the most significant factors in today's marriage market (Mahoney et al., 2008; Mahoney 2010; McClendon, 2016; Chebotareva, 2014, 2015). Perry $(2015,2016)$ proved that the spouses' religiosity match interrelates with their marital satisfaction. Petts reports that the spouses' religiosity affects their marriage differently in different cultures (Petts, 2016). In general, the researches of marital adjustment and satisfaction in crosscultural couples give controversial results. Some studies suggest that in cross-cultural couples different cultural background and life values of spouses cause greater conflicts and accordingly, these couples are less satisfied with their marriages (Cooney \& Radina, 2000; Gaines \& Agnew, 2003; Kelley \& Thibaut, 1978; Killian, 2002;). Many studies show that homogenous marriages are more satisfying and stable (Heaton \& Pratt 1990; Call \& Heaton 1997; Curtis \& Ellison 2002; Heaton, 2002; Myers, 2006). Other studies proved the equal level of satisfaction and sustainability of cross-cultural and monocultural marriages (Gaines \& Brennan, 2000). But there is also some scientific evidence, that marital adjustment and relationship satisfaction in cross-cultural families may be greater, than in monocultural ones (Stringer, 1991; Troy, Lewis-Smith, \& Laurenceau, 2006). Among factors that help the couples to cope with the difficulties of cross-cultural marriages, illuminated in researches, are the spouses' positive ethnic identity, positive attitudes to the partner's culture (Killian, 2002; Model \& Fisher, 2002).

Many researchers of the problem agree that one of the most acute problems here is matching the spouses' values and attitudes. There is also a wide range of points of view on this matter. On the one hand, it is assumed that cross-cultural marriages are entered mostly by people who are either already culturally assimilated, or who have certain values, such as universalism, tolerance and multiculturalism. On the other hand, it is assumed that the spouses' worldviews matching is the main challenge of such marriages (Sokolovsky, 2003). Somewhere in the middle of this continuum there are ideas that cultural differences may be reduced by similarities in education and personal development (Zhenchao Qian et all, 2001), or that two individuals create their own "relational culture", not arguing with their spouses' cultural values (Wood, 2000; Gaines \& Brennan, 2001). Some researches show that in some cases people in a foreign cultural environment tend to maintain their commitment to the values and traditions of their native culture (Maslova \& Bui, 2015), and migrants may "conserve" their traditional values inside their crosscultural families.

It is important to study the life values of spouses in cross-cultural marriages, taking into account their family values, attitudes to family life (Fischer \& Schwartz, 2011). The studies of age- and gender-specific attitudes to family life in Russia have shown that behind the similarity of these attitudes there are differences in personal meanings (implementations of life values) between these groups (Chebotareva, 2016).

Thus, the empirical study has been conducted with the aim to analyze the differences in life and family values and their interactions between the spouses from cross-cultural and monocultural couples, and to understand the psychological mechanisms of implementation of cultural and personal life values in family - life attitudes. 


\section{Methods and Procedure}

Participants. 330 people took part in the empirical study, including 85 cross-cultural couples (170 persons) and 80 monocultural couples (160 persons). Cross-cultural couples were Arab-Christian (men were mostly from Palestine and from some other Arab countries; women were Russian (90\%), Belarusian and Ukrainian). All the cross-cultural couples had been living in Russia (mostly in the capital) for not less than 3 years. Among monocultural couples there were 50 Arab families leaving in Arab countries and 30 Russian families, living in Russia, mostly in Moscow and other big cities. All three sub-samples compositions were aligned in their main socio-demographic characteristics. The age of the participants was from 22 to 47 years old. The average age of cross-cultural spouses was 32 years old; monocultural Arab spouses were 30.6 years old; monocultural Russian spouses were 33 years old. Most families (98\%) had from 1 to 3 children living in families, only a few families had 4-5 children. The level of the respondents' education varied from secondary (18\%) to higher $(73 \%)$ education. The cross-cultural couples often reported that they met at the university (42\%), at work (27\%), through friends and colleagues (21\%). The composition of the cross-cultural sample is characteristic for this type of cross-cultural marriages in Russia. The socio-demographic characteristics of monocultural subsamples were aligned with the cross-cultural group, but they are somewhat different from the general national demographic. To ensure greater homogeneity of the sample, we took into account the stage of the families' life cycle, excluding families without children, with newborn children, and with older children who had already left their parental family. Also, people of a higher and lower social status are not represented in the sample.

Techniques. To measure the degree of importance of various life values S. Schwartz' "Value Survey" in V.N. Karandashev's adaptation was applied. It is based on the development of M. Rokeach understanding of life values (Schwartz, 2009). It measures such value types as: power, achievement, hedonism, stimulation, self-direction, universalism, benevolence, tradition, conformity, security. Stimulus material in this technique consists of two parts: for normative ideals and for individual behavioral attitudes. The average score on each scale of the first part ranges from 1 to 7 , of the second part from 1 to 4 . The ratio of different scales is estimated, which suggests a certain degree of significance of some values over the others for the respondent.

The attitudes of the respondents to family values were investigated with two techniques: "Test of Attitudes to Family Life” by Yu. Alyoshina, L. Gozman, \& E. Dubovskaya and the questionnaire "Marital Role Expectations and Aspirations" by A.N. Volkova. The first technique consists of 40 statements, expressing the particular position on 10 important areas of family life: positive representations about people in general; sense of duty; role of children in family life; importance of the spouses' joint activity; attitude to divorce (its acceptance or rejection); attitude to romantic love (traditional representations vs pragmatical point of view); importance of sex in family relations; readiness to speak openly about sex or avoiding this topic; attitudes to woman's role in family (traditional or not); attitudes to thrift. 
The technique "Marital Role Expectations and Aspirations" allows to identify:

1) The respondents' representations of the importance of the different family life spheres, such as sexual relations, personal identification with each other, parenting, social activity of each spouse, household duties, moral and emotional support (psychotherapeutic function), the visual appeal. These indicators, reflecting the basic functions of the family, constitute the block of family values;

2) The respondents' representations about the desired distribution of the family roles between husband and wife. This part consists of two units: of role expectations, what the respondent would like his or her partner to do; and - of aspirations, what the respondent would like to take on himself or herself.

“Marital Satisfaction Test” by V. Stolin, T. Romanova, \& G.Butenko was used for express- measuring of general level of emotional marital satisfaction of the respondents. It is represented by one-dimensional scale, consisting of 24 statements related to different areas of family interrelations. The overall level of marital satisfaction, in accordance with the key, can be assigned to one of the 7 categories from "completely unsuccessful" to "completely happy".

We used the snowball sampling method: first, the respondents were recruited by the students of the University among their acquaintances, then, these respondents recruited their acquaintances and so on. We also recruited the participants of the cross-cultural sub-sample from the special forums, where the problems of inter-faith, especially MuslimChristian ones, are discussed. The surveys were conducted personally during 2-3 meetings, 30 minutes each. All the participants were informed by the interviewers about the aims of the study before the survey was administered.

Statistical analysis for the data presented in the paper was performed using the descriptive statistics, Tukey multiple comparison of means, Mann-Whitney U-test, Spearman rank correlations method.

\section{Results and Discussion}

A comparative analysis of the importance of life values for the spouses from crosscultural and monocultural marriages was conducted. Since belonging to a particular culture plays an important role in the formation of the values hierarchy, we decided to conduct multiple variance analysis that identified the impact of gender, nationality, family type factors, as well as their combined influence. In this paper we will consider the impact of the "type of the family" factor (i.e. cross-cultural or monocultural), excluding the influence of the other factors considered. The average indexes of the importance of life values at the normative level and at the level of individual priorities, as well as the results of multiple variance analysis are presented in Table 1.

At the level of normative ideals, the variance analysis revealed the strongest difference in the value of stimulation. Regardless of their nationality, monocultural families are more eager to get new impressions, entertainment, changing situation. Apparently, a relationship with a representative of another culture completely satiates this need and makes it not relevant. There are also strong differences in the levels of importance of normative values: conformity, benevolence, universalism, self-direction, achievement. All these values are more important for monocultural families. 
Means of life values importance for cross-cultural and monocultural families and Tukey multiple comparison test

\begin{tabular}{|c|c|c|c|c|c|c|}
\hline \multirow[b]{2}{*}{ Life Values } & \multicolumn{2}{|c|}{ Means } & \multirow[b]{2}{*}{ Sum Sq } & \multirow[b]{2}{*}{ Mean Sq } & \multirow[b]{2}{*}{ F-value } & \multirow[b]{2}{*}{$\operatorname{Pr}(>F)$} \\
\hline & $\begin{array}{c}\text { Cross-cultural } \\
(n=170)\end{array}$ & $\begin{array}{l}\text { Monocultural } \\
(n=160)\end{array}$ & & & & \\
\hline \multicolumn{7}{|c|}{ Normative Values } \\
\hline Conformity & 4.01 & 4.23 & 29.4 & 29.38 & 10.213 & .001 \\
\hline Tradition & 4.05 & 3.82 & .1 & .09 & .029 & .866 \\
\hline Benevolence & 4.32 & 4.64 & 32.4 & 32.41 & 9.956 & .002 \\
\hline Universalism & 4.00 & 4.02 & 45.7 & 45.65 & 8.817 & .003 \\
\hline Self-Direction & 4.33 & 4.45 & 31.3 & 31.31 & 8.323 & .004 \\
\hline Stimulation & 2.85 & 3.16 & 145.8 & 145.79 & 42.635 &, 000 \\
\hline Hedonism & 3.95 & 3.79 & 15.8 & 15.82 & 4.876 & .028 \\
\hline Achievement & 4.17 & 4.33 & 25.9 & 25.91 & 9.662 & .002 \\
\hline Power & 4.19 & 3.56 & .3 & .26 & .056 & .814 \\
\hline Security & 4.78 & 4.49 & 1.6 & 1.64 & .518 & .472 \\
\hline \multicolumn{7}{|c|}{ Personal Values } \\
\hline Conformity & 1.89 & 1.56 & 106.5 & 106.50 & 41.24 & .000 \\
\hline Tradition & 1.87 & 1.59 & 84.8 & 84.82 & 26.45 & .000 \\
\hline Benevolence & 1.75 & 1.59 & 93.3 & 93.30 & 48.86 & .000 \\
\hline Universalism & 1.89 & 1.35 & 99.0 & 99.00 & 35.98 & .000 \\
\hline Self-Direction & 1.89 & 1.16 & 90.5 & 90.49 & 36.84 & .000 \\
\hline Stimulation & 1.56 & 1.69 & 251.3 & 251.28 & 71.24 & .000 \\
\hline Hedonism & 1.69 & 1.54 & 139.2 & 139.22 & 49.49 & .000 \\
\hline Achievement & 1.81 & 1.60 & 159.9 & 159.95 & 60.10 & .000 \\
\hline Power & 1.51 & 1.80 & 202.2 & 202.21 & 50.37 & .000 \\
\hline Security & 1.97 & 1.26 & 70.3 & 70.33 & 25.86 & .000 \\
\hline
\end{tabular}

On the one hand, it is obvious that it is easier to decide to get married to a person from another culture for the people for whom the general cultural normative values are not so important. On the other hand, it is possible that the mutual influence of the culturalspecific values of the two spouses mitigates the normative ideals of each of them, making them less pronounced. The desire to enjoy life is more characteristic for cross-cultural families. Perhaps, it is this value that determines the willingness to seek a life partner in another culture, hoping to overcome the limitations of his or her own culture.

At the level of personal values, the statistically significant differences were found in the importance of all values at a very high level of significance. At this level, most values are more important for the representatives of cross-cultural families. Possibly, having abandoned the influence of normative values, these people are more clearly aware of their individual aspirations. In monocultural families, only values of stimulation and power are more pronounced. The high personal importance of this value can be one of the reasons why these people prefer to choose a partner within their culture, thereby avoiding the role of a minority in a foreign cultural environment.

The variance analysis of attitudes to family life revealed only one significant difference between the representatives of cross-cultural and monocultural marriages. Monocultural families are much more oriented toward the traditionally understood, idealized romantic love $(p=.00002)$, which is in full agreement with the predominance of normative values 
in monocultural families described above. In cross-cultural families, the ideas of love are more mature and pragmatic.

The comparison of the degree of different family spheres importance revealed significantly greater importance of the parental sphere for monoculture families $(p=.05)$, which also agrees with a greater focus on general cultural values. In addition, there is a tendency to the significance $(p=.06)$ in the difference in sexual sphere. This sphere is more important for cross-cultural families, which also agrees with the data described earlier about the prevalence of hedonism in this group. In general, the results suggest that in cross-cultural couples the spousal interpersonal relations are more important, for the monocultural ones - a family is perceived as a resource for fulfilling some other life values outside the family sphere.

The analysis of the spouses' claims on the family roles fulfillment revealed a highly significant difference $(p=.0001)$ in the spouses' striving for outside-family social activity. The representatives of monocultural families are much more interested in self-actualization in the external sphere. Perhaps this difference is due to the fact that in monocultural families both spouses live in their native culture, it is easier for them to interact with the social environment, while in cross-cultural families one of the spouses (man in our case) is in a foreign culture environment, it may be difficult for him to socialize. Culturalspecific gender stereotypes may also be affected. Since in our study cross-cultural families are represented by Arab men and Russian women, Muslim men may interfere with the active social contacts of their Russian wives.

At the trend level $(p=.06)$ it was revealed that the members of monocultural families are more willing to perform parental functions, which is consistent with the data on the higher importance of the parental function for them. It is also possible that cross-cultural Arab-Russian families are affected by gender attitudes to the distribution of responsibilities, and the decrease in the average indicators in this sample occurs primarily at the expense of the male respondents. This idea is confirmed by a pairwise comparison of gender subsamples. The level of aspirations for the performance of the parental role in women from cross-cultural and monocultural families does not significantly differ $(p=.47)$, and the differences between the men of the two groups are at a high level of significance $(p=.02)$.

There are no statistically significant differences in the expectations regarding spouses' performance of certain family roles.

After analyzing the family values and attitudes of spouses from two types of families, the question arises: how much these people are satisfied with this state of affairs. In order to answer this question, we compared the levels of marital satisfaction in these types of couples. Significant differences were found in this indicator $(p=.000004)$. The average level of marital satisfaction in cross-cultural families is 25.6 points, which, according to the test standards, refers to the "more dissatisfied, than satisfied" type, and in monocultural families it is 33.2 points, which, according to the test standards, reflects quite a satisfactory level. Perhaps the lower level of marital satisfaction in cross-cultural families is associated with the high importance of marital relations, the desire to realize in the family sphere mostly not the normative life values, but their own individual attitudes, the importance of obtaining pleasure from life. For the spouses from monocultural families, the sphere of external social realization is no less important than the sphere of intra-family relations. 
Perhaps they have more resources either to compensate for some failures in each of the spheres, or to mutually enrich the two important spheres of life.

According to the results above, we assume that spouses from cross-cultural families are more likely to connect their expectations of their life values realizing with the family sphere, limiting their interaction with their social environment and thereby limiting their opportunities and overloading the expectations of the sphere of family relations. To test this assumption, we conducted a correlation analysis of the indicators of the importance of life and family values.

Let's start with the analysis of the correlations of the levels of life values importance with the levels of marital satisfaction (Table 2). From the table, it is clear at a glance that the above mentioned assumption is confirmed. In persons from cross-cultural families the importance of all personal values is inversely related to marital satisfaction. Only the correlations with the values of traditions and power did not reach the level of statistical significance.

Table 2

Correlations of life values with marital satisfaction of persons from cross-cultural and monocultural families

\begin{tabular}{|l|l|l|l|l|l|}
\hline \multirow{2}{*}{ Normative Values } & \multicolumn{2}{|c|}{ Marital Satisfaction } & \multirow{2}{*}{ Personal Values } & \multicolumn{2}{c|}{ Marital Satisfaction } \\
\cline { 2 - 3 } & Cross-cultural & Mono-cultural & & Cross-cultural & Mono-cultural \\
\hline Conformity & -.079 & .000 & Conformity & -.272 & -.121 \\
\hline Tradition & -.005 & .103 & Tradition & -.108 & -.097 \\
\hline Benevolence & .038 & .255 & Benevolence & -.167 & -.079 \\
\hline Universalism & -.118 & .209 & Universalism & -.228 & -.236 \\
\hline Self-Direction & -.061 & .375 & Self-Direction & -.226 & .000 \\
\hline Stimulation & -.167 & .072 & Stimulation & -.246 & .231 \\
\hline Hedonism & -.069 & .062 & Hedonism & -.303 & .231 \\
\hline Achievement & -.050 & .172 & Achievement & -.269 & .324 \\
\hline Power & .054 & -.17 & Power & -.145 & .294 \\
\hline Security & .045 & .224 & Security & -.361 & -.106 \\
\hline
\end{tabular}

Note. $p \leq .05$ is in grey background.

For the spouses from monocultural families, the personal values of achievement and power are directly related to the marital satisfaction. This is consistent with the data that in monocultural families the spouses are more oriented toward self-realization in the external sphere, the family is considered primarily as a resource for achieving external goals. Normative life values mostly are not related to the level of marital satisfaction. The exceptions are: for cross-cultural families - the value of stimulation, for monocultural families - the value of self-direction. As it was mentioned, in cross-cultural families the value of stimulation is much less pronounced than in monocultural families. Perhaps the negative interaction of this value with the marital satisfaction is due to the greater orientation of these spouses on the intrafamily processes, relative isolation from the social environment. Perhaps the desire of the spouses for novelty of impressions, on the one hand, is perceived by their partners as a threat to their marriage, on the other hand, this desire may be discouraged by family rules. The direct connection of the value of independence with the marital satisfaction in monocultural families is quite consistent 
with the identified preferential orientation of these families to self-actualization in the external sphere.

Next, let us consider the interaction of importance of different spheres of family life for the spouses with their life values (Tables 3, 4). In general, cross-cultural families (Table 3) have a large number of statistically significant links between the normative life values and the indicators of the importance of family functions. The greatest number of connections is found in the psychotherapeutic sphere, parental spheres and the sphere of social activity, which are leading in this group's system of family values. Apparently, it is in these spheres that persons from cross-cultural families see the opportunities for realizing their life values. In this group, there are no significant links between the normative life values and the importance of visual appeal of the spouses for the partners. And the sexual sphere of family life revealed only the inverse relations with normative life values, especially with the values of universalism, conformity and benevolence. As mentioned above, crosscultural families differ from monocultural ones in a higher significance of this sphere. Apparently, in the representations of this group, a strong orientation toward normative general cultural values contradicts the desire for physical pleasure in marital relations.

In the correlations of individual values, the two main groups of links were found: the collectivist values such as conformism, traditions, benevolence and universalism are directly related to many family spheres that are important for the people of this group; while the individualistic values such as hedonism and power are linked to these spheres inversely. It is interesting that the importance of the sexual sphere, which is inversely related to the attitudes to tradition and benevolence, is directly related to the values of achievement and power. Also, the value of achievements is directly related to the importance of the parental function.

Thus, it can be assumed that the persons in cross-cultural marriages connect the possibilities of their normative life values realization with the family life, especially with such important spheres as psychotherapeutic, parental and social activity. But in real day-to-day activities, they do not always manage to realize their life goals in the family sphere. And if the collectivist values remain connected with the family functions, then such individualistic values as hedonism and power are perceived as incompatible with family functions.

Table 3

Correlations of life values with importance of family spheres of persons from cross-cultural families

\begin{tabular}{|c|c|c|c|c|c|c|c|}
\hline \multirow[b]{2}{*}{ Life values } & \multicolumn{7}{|c|}{ Family spheres } \\
\hline & Sex & $\begin{array}{l}\text { Identification } \\
\text { with partner }\end{array}$ & Household & Parenting & $\begin{array}{l}\text { Social } \\
\text { activity }\end{array}$ & $\begin{array}{c}\text { Psycho- } \\
\text { therapeutic }\end{array}$ & $\begin{array}{l}\text { Visual } \\
\text { appea }\end{array}$ \\
\hline \multicolumn{8}{|c|}{ Normative Values } \\
\hline Conformity & -.18 & .11 & .20 & .25 & .17 & .30 & .09 \\
\hline Tradition & -.12 & .15 & .11 & .27 & .23 & .35 & .13 \\
\hline Benevolence & -.18 & .10 & .12 & .27 & .22 & .32 & .06 \\
\hline Universalism & -.24 & .00 & .10 & .12 & .08 & .20 & -.01 \\
\hline Self-Direction & -.12 & .12 & .08 & .21 & .14 & .26 & .03 \\
\hline Stimulation & -.11 & .03 & .00 & .01 & .07 & .03 & -.03 \\
\hline Hedonism & .06 & .20 & .12 & .20 & .20 & .33 & .10 \\
\hline Achievement & -.09 & .16 & .10 & .23 & .22 & .33 & -.01 \\
\hline
\end{tabular}


Table 3(End)

\begin{tabular}{|l|l|l|l|l|l|l|l|}
\hline \multirow{2}{*}{ Life values } & \multicolumn{7}{|c|}{ Family spheres } \\
\cline { 2 - 8 } & \multicolumn{1}{|c|}{ Sex } & $\begin{array}{c}\text { Identification } \\
\text { with partner }\end{array}$ & Household & Parenting & $\begin{array}{c}\text { Social } \\
\text { activity }\end{array}$ & $\begin{array}{c}\text { Psycho- } \\
\text { therapeutic }\end{array}$ & $\begin{array}{c}\text { Visual } \\
\text { appeal }\end{array}$ \\
\hline Power & .07 & .13 & .15 & .14 & .15 & .23 & -.06 \\
\hline Security & -.13 & .07 & .17 & .29 & .23 & .33 & .09 \\
\hline \multicolumn{7}{|c|}{ Personal Values } \\
\hline Conformity & -.13 & -.03 & .21 & .27 & .10 & .18 & .31 \\
\hline Tradition & -.15 & -.09 & .07 & .18 & .09 & .14 & .19 \\
\hline Benevolence & -.18 & -.01 & .13 & .19 & .13 & .19 & .21 \\
\hline Universalism & -.14 & .04 & .13 & .19 & .12 & .18 & .10 \\
\hline Self-Direction & -.1 & -.05 & .13 & .19 & .12 & .17 & -.06 \\
\hline Stimulation & .07 & -.01 & .13 & .19 & .11 & .16 & .00 \\
\hline Hedonism & .03 & .05 & .13 & .19 & .11 & .15 & -.10 \\
\hline Achievement & .19 & .02 & .13 & .19 & .11 & .15 & .13 \\
\hline Power & .16 & -.02 & .13 & .19 & .10 & .14 & -.20 \\
\hline Security & -.06 & -.00 & .02 & .15 & -.01 & .04 & .07 \\
\hline
\end{tabular}

Note. $p \leq .05$ is in grey background.

In monocultural families (Table 4) in general, life values are much less connected with family functions, which again confirms the greater focus of this group on external selfrealization. In this group, in contradiction to cross-cultural families, spouses associate their personal values more closely with family functions than normative ones. The psychotherapeutic function is connected only to values of self-direction and security. At the personal level, all the links of this family sphere with the values are the reverse ones. These data suggest that the normative life values of spouses in cross-cultural marriages are more in line with their desire to realize psychotherapeutic functions in their families; at the level of personal priorities, only collectivist attitudes are associated with this function.

Table 4

Correlations of life values with importance of family spheres of persons from mono-cultural families

\begin{tabular}{|c|c|c|c|c|c|c|c|}
\hline \multirow[b]{2}{*}{ Life values } & \multicolumn{7}{|c|}{ Family spheres } \\
\hline & Sex & $\begin{array}{l}\text { Identification } \\
\text { with partner }\end{array}$ & Household & Parenting & $\begin{array}{l}\text { Social } \\
\text { activity }\end{array}$ & $\begin{array}{l}\text { Psycho- } \\
\text { therapeutic }\end{array}$ & $\begin{array}{l}\text { Visual } \\
\text { appeal }\end{array}$ \\
\hline \multicolumn{8}{|c|}{ Normative Values } \\
\hline Conformity & -.27 & -.08 & .21 & .28 & .11 & .08 & -.21 \\
\hline Tradition & -.28 & -.03 & .18 & .23 & -.03 & .05 & -.15 \\
\hline Benevolence & -.19 & -.05 & .18 & .14 & .05 & .15 & -.18 \\
\hline Universalism & -.14 & .06 & .09 & .07 & -.02 & .19 & -.11 \\
\hline Self-Direction & -.13 & -.04 & .13 & -.03 & .01 & .28 & -.18 \\
\hline Stimulation & -.26 & .08 & .02 & -.08 & -.29 & -.02 & -.30 \\
\hline Hedonism & -.08 & -.04 & .23 & -.01 & -.18 & -.06 & -.16 \\
\hline Achievement & -.20 & -.11 & .19 & .12 & -.08 & .06 & -.26 \\
\hline Power & -.20 & .02 & .24 & .14 & .09 & .12 & .01 \\
\hline Security & -.43 & .13 & .22 & .33 & .11 & .29 & -.01 \\
\hline \multicolumn{8}{|c|}{ Personal Values } \\
\hline Conformity & -.10 & -.40 & -.16 & -.25 & -.50 & -.42 & -.57 \\
\hline Tradition & .15 & -.20 & -.08 & -.19 & -.27 & -.20 & -.12 \\
\hline
\end{tabular}


Чеботарева Е.Ю., Джабер Хасан М.А. Вестник РУДН. Серия: Психология и педагогика. 2017. T. 14. № 3. C. $311-325$

Table 4 (End)

\begin{tabular}{|l|l|l|l|l|l|l|l|}
\hline \multirow{3}{*}{ Life values } & \multicolumn{7}{c|}{ Family spheres } \\
\cline { 2 - 8 } & Sex & $\begin{array}{c}\text { Identification } \\
\text { with partner }\end{array}$ & Household & Parenting & $\begin{array}{c}\text { Social } \\
\text { activity }\end{array}$ & $\begin{array}{c}\text { Psycho- } \\
\text { therapeutic }\end{array}$ & $\begin{array}{c}\text { Visual } \\
\text { appeal }\end{array}$ \\
\hline Benevolence & -.07 & -.12 & .08 & .02 & -.13 & -.34 & -.39 \\
\hline Universalism & .16 & -.17 & .13 & -.17 & -.26 & -.31 & -.12 \\
\hline Self-Direction & -.02 & -.29 & -.04 & -.01 & -.22 & -.37 & -.35 \\
\hline Stimulation & -.04 & -.15 & .07 & .04 & -.25 & -.27 & -.53 \\
\hline Hedonism & .08 & -.33 & -.23 & -.10 & -.17 & -.26 & -.56 \\
\hline Achievement & .15 & -.37 & -.18 & -.05 & -.28 & -.24 & -.38 \\
\hline Power & .13 & -.16 & -.12 & -.08 & -.34 & -.23 & -.38 \\
\hline Security & .16 & -.47 & -.30 & -.37 & -.52 & -.60 & -.48 \\
\hline
\end{tabular}

Note. $p \leq .05$ is in grey background.

For the monocultural families, at the normative level only the values of self-direction and security are related to the psychotherapeutic family function, which apparently corresponds to the modern attitudes to family life, i.e. simultaneous satisfaction of the needs for autonomy and for affiliation are expected. But at the behavioral level, these and a number of other individual values are linked inversely to the psychotherapeutic function of the family. Perhaps these data indicate that in monocultural families, spouses fail to realize this function in a way they would like, and the high significance of the corresponding life values at the behavioral level leads to a devaluation of this family function.

The importance of the sexual sphere of family life, like in cross-cultural families, is inversely related to a number of normative life values, but at the level of personal priorities these links do not reach the level of significance. Perhaps in these families in everyday life the spouses do not consider the realization of their sexual needs to be contrary to some life goals. But there is a large number of inverse correlations of many life values with the importance of family functions of visual appeal for a partner, psychotherapeutic function, personal identification with the spouse and social activity.

The personal value of security found significant inverse correlations with almost all spheres of family life, except for the sexual sphere. These data, in our opinion, confirm the above-mentioned assumption, that the spouses in monocultural families often abandon their attempts to implement their actual life goals in the family sphere.

\section{Conclusions}

As a result of the study, we can conclude that the persons from cross-cultural and monocultural marriages have different life and family values hierarchies. The crosscultural spouses, in comparison with monocultural ones, are more focused on their personal values than on normative (widely shared in their culture) values. At the level of normative life values spouses in cross-cultural couples are much less focused on the novelty of impressions and much more - on enjoying life. At the level of personal priorities, the spouses in cross-cultural couples consider values of power and domination less important. In general, the differences in family values reflect the fact, that for crosscultural couples the spousal interpersonal relations are more important, for monocultural 
ones - a family is perceived as a resource for fulfilling some other life values outside family sphere. In the distribution of family responsibilities, cross-cultural spouses are less eager for social activity outside the family.

Persons in cross-cultural and monocultural families incarnate their life values in family life differently. In cross-cultural marriages the spouses see the opportunities for their normative life goals realizing in the family, especially in its psychotherapeutic and parental spheres, as well as in social activity outside the family. But in their real day-to-day activities, they do not always manage to realize their life goals in the family sphere, probably because of the difficulties in interacting with their social environment, which can come from the fact that their families are more enclosed, which in turn leads to a decrease of marital satisfaction. In the cross-cultural spouses' representations, collectivist values are more related to family functioning, but the individualistic values such as hedonism and power are perceived as incompatible with the successful functioning of the family.

The marital satisfaction of cross-cultural families of the studied type on average is much lower than in monocultural families. The reduced marital satisfaction is associated with the high importance of most personal life values, as well as the value of stimulation at the normative level. In monocultural families, marital satisfaction is directly related to the normative value of self-direction and personal attitudes to external achievements, social status and power.

The research data can be used by psychologists and social services to help cross-cultural families in realizing their potential more fully and overcoming the limitations identified in the study. In particular, a strong emotional connection between the spouses can be viewed as a resource to support a foreign spouse in enhancing his or her contacts with the social environment. On the other hand, it will be useful to raise the level of personal differentiation of spouses in such families, that can help the spouses living in foreign culture to understand their own needs and goals more clearly and to communicate with their spouses and other people more clearly and openly. The connection of personal values with the family sphere perceived by cross-cultural couple can serve as a basis for increasing their marital satisfaction and their overall subjective well-being.

Limitations of the study. Due to the limited volume, this paper presents part of the results of the study. In particular, the results of pairwise comparative analysis of crosscultural couples with monocultural pairs are not presented, only some separate results are mentioned, which are important for explaining the results described here. A separate discussion is required for the consistency of the spouses' views within the pairs. The conclusions of this study should be disseminated to other cross-cultural families with caution, since the sample is specific in the cultures combination and their country of residence. To identify common patterns, studies of such couples living in the husbands' home countries or in any third country, as well as studies of other types of cross-cultural marriages in Russia, are required. For example, marriages of Russians to the persons from former Soviet republics will be specific for each region, depending on the social niche occupied by different ethnic groups in the country. Naturally, we need to compare the data we obtained with the results of studies of other types of cross-cultural families around the world. A large number of cultural, social, political and economic factors affect the relations in the family. It would also be useful to investigate the attitudes and relations of cross-cultural spouses at different stages of the family's life cycle. 


\section{REFERENCES}

Call, V.R.A. \& Heaton, T.B. (1997). Religious influence on marital stability. Journal for the Scientific Study of Religion, 36(3), 382-392. doi: 10.2307/1387856.

Chebotareva, E. (2014). Psychological factors of ethnic extremism in Muslim youth. Mediterranean Journal of Social Sciences, 5 (22), 140-148. doi: 10.5901/mjss.2014.v5n22p140.

Chebotareva, E. (2015). Cultural Specifics of Life Values and Subjective Well-Being. Mediterranean Journal of Social Sciences, 6 (2 S5), 301-307. doi: 10.5901/mjss.2015.v6n2s5p301.

Chebotareva, E.Yu. (2016). Tsennostnye orientatsii i ustanovki k semeinoi zhizni v dobrachnyi period: gendernyi aspect. Problemnoe pole sovremennoi sem'i. Moscow: MGGU im. Sholokhova, 208-213. (In Russ.).

Cooney, T. \& Radina, M. (2000). Adjustment problems in adolescence: Are multiracial children at risk? American Journal of Orthopsychiatry, 70 (4), 433-444. doi: 10.1037/h0087744.

Curtis, K.T., \& Ellison, C.G. (2002). Religious heterogamy and marital conflict: Findings from the national survey of families and households. Journal of Family Issues, 23(4), 551-576. doi: $10.1177 / 0192513 \times 02023004005$.

Fischer R. \& Schwartz S. (2011). Whence differences in value priorities? Individual, cultural, or artifactual sources. Journal of Cross-Cultural Psychology, 42 (7), 1127-1144. doi: $10.1177 / 0022022110381429$.

Gaines, S. \& Brennan, K. (2001). Establishing and maintaining satisfaction in multicultural relationships. In J. Harvey \& A. Wenzel (Eds.). Close Romantic Relationships: Maintenance and Enhancement (pp. 237-253). Mahwah, NJ: Lawrence Erlbaum Associates, Inc.

Gaines, S. \& Agnew, C. (2003). Relationship maintenance in inter-cultural couples: An interdependence analysis. In D. Canary \& M. Dainton (Eds.). Maintaining Relationships Through Communication (pp. 231-253). Mahwah, NJ: Lawrence Erlbaum Associates, Inc.

Heaton, T.B., \& Pratt, E.L. (1990). The effects of religious homogamy on marital satisfaction and stability. Journal of Family Issues, 11(2), 91-207. doi: 10.1177/019251390011002005.

Heaton, T.B. (2002). Factors contributing to increasing marital stability in the United States. Journal of Family Issues, 23(3), 392-409. doi: 10.1177/0192513x02023003004.

Kelley, H. \& Thibaut, J. (1978). Interpersonal relations: A theory of interdependence. New York: Wiley.

Killian, K. (2001). Crossing borders: Race, gender, and their intersections in inter-racial couples. Journal of Feminist Family Therapy, 13, 1-31.

Killian, K. (2002). Dominant and marginalized discourses in inter-racial couples' narratives: Implications for family therapists. Family Process, 41(4), 603-618. doi: 10.1111/j.1545-5300.2002.00603.x.

Mahoney, A., Pargament, K.I., Tarakeshwar, N., \& Swank, A.B. (2008). Religion in the home in the 1980s and 1990s: A meta-analytic review and conceptual analysis of links between religion, marriage, and parenting. Psychology of Religion and Spirituality, S(1), 63-101. doi: 10.1037/1941-1022.s.1.63.

Mahoney, A. (2010). Religion in families, 1999-2009: A relational spirituality framework. Journal of Marriage and Family, 72(4), 805-827. doi: 10.1111/j.1741-3737.2010.00732.x.

Maslova, O.V. \& Bui, D.T. (2015) Izmenenie tsennostnykh orientatsii v'etnamskikh studentov v Rossii: rezul'taty empiricheskogo issledovaniya. Vestnik Kemerovskogo gosudarstvennogo universiteta, (3), 179-184. (In Russ.).

McClendon, D. (2016) Religion, Marriage Markets, and Assortative Mating in the United States. Journal of Marriage and Family, 78 (5), 1399-1421. doi: 10.1111/jomf.12353.

Model, S. \& Fisher, G. (2002). Unions between Blacks and Whites: England and the US compared. Ethnic and Racial Studies, 25(5), 728-754. doi: 10.1080/0141987022000000240.

Myers, S.M. (2006). Religious homogamy and marital quality: Historical and generational patterns, 1980-1997. Journal of Marriage and Family, 68(2), 292-304. doi: 10.1111/j.1741-3737.2006.00253.x. 
Ortega, S.T., Whitt, H.P. \& William, J.A. (1988). Religious homogamy and marital happiness. Journal of Family Issues, 9(2), 224-239. doi: 10.1177/019251388009002005.

Perry, S.L. (2015). A Match Made in Heaven? Religion-Based Marriage Decisions, Marital Quality, and the Moderating Effects of Spouse's Religious Commitment. Social Indicators Research, 123 (1), 203-225. doi: 10.1007/s11205-014-0730-7.

Perry, S.L (2016). Spouse's Religious Commitment and Marital Quality: Clarifying the Role of Gender. Social Science Quarterly, 97 (2), 476-490. doi: 10.1111/ssqu.12224.

Petts, R.J. (2016) Religious homogamy, race/ethnicity, and parents' relationship stability. Sociological Focus, 49 (3), 163-179. doi: 10.1080/00380237.2016.1135027.

Sokolovskii, S.V. (2003). Podkhody k izucheniyu etnicheskoi identifikatsii. SOTsIS, (3), 23-28. (In Russ.).

Stringer, H. (1991). A comparison of selected marital characteristics in black-white interracial marriages and same race marriages. Unpublished doctoral dissertation, The Ohio State University, Columbus, $\mathrm{OH}$.

Schwartz S.H. (2009). Culture matters: National value cultures, sources and consequences. In C.-Y. Chiu, Y.Y. Hong, S. Shavitt, \& R.S. Wyer (Eds). Understanding culture: Theory, research and application (pp. 127-150). N.Y.: Psychology Press.

Troy, A., Lewis-Smith, J., \& Laurenceau, J. (2006). Interracial and intraracial romantic relationships: The search for differences in satisfaction, conflict, and attachment style. Journal of Social and Personal Relationships, 23(1), 65-80. doi: 10.1177/0265407506060178.

Zhenchao Q., Sampson L.B. \& Stacey D.R. (2001) Asian American Interracial and Interethnic Marriages: Differences by Education and Nativity. The International Migration Review, 35 (2), pp. 557-586. doi: 10.1111/j.1747-7379.2001.tb00029.x.

Wood, J. (2000). Relational communication: Continuity and change in personal relationships (2nd ed.). Belmont, CA: Wadsworth.

\title{
Article history:
}

Received 17 March 2017

Revised 21 May 2017

Accepted 14 June 2017

\section{For citation:}

Chebotareva, E.Y., Jaber, H.M.A. (2017). Life Values of Persons in Cross-Cultural (Arab-Russian) and Monocultural Marriages and Their Representation in Family Sphere. RUDN Journal of Psychology and Pedagogics, 14 (3), 311-325. DOI 10.22363/2313-1683-2017-14-3-311-325

\author{
Bio Note: \\ Elena Y. Chebotareva ${ }^{-} \mathrm{PhD}$, Associate professor. Associate professor of: the Department of Social \\ and Differential Psychology of Peoples' Friendship University of Russia (RUDN University); the \\ Department of Child and Family Psychotherapy of Moscow State University of Psychology and \\ Education; Master program "Systemic family psychotherapy" of National Research University \\ "Higher School of Economics”. E-mail: chebotareva_eyu@rudn.university
}

Hasan M.A Jaber - Post graduate student of the Department of Social and Differential Psychology of Peoples' Friendship University of Russia (RUDN University). E-mail: alone5544332211@ mail.ru

The authors' contributions: Chebotareva E.Yu. - the study concept and design, analysis of the data obtained, the text writing; Hasan M.A. Jaber - the empirical data collection. 


\title{
ЖИЗНЕННЫЕ ЦЕННОСТИ ЛЮДЕЙ, СОСТОЯЩИХ В МЕЖКУЛЬТУРНЫХ (АРАБО-РУССКИХ) И МОНОКУЛЬТУРНЫХ БРАКАХ, И ИХ РЕАЛИЗАЦИЯ В СЕМЕЙНОЙ СФЕРЕ
}

\author{
Е.Ю. Чеботарева ${ }^{1,2,3}$, Х.М.А. Джабер ${ }^{1}$ \\ ${ }^{1}$ Российский университет дружбы народов \\ ул. Миклухо-Маклая, 6, Москва, Россия, 117198 \\ ${ }^{2}$ Московский государственный психолого-педагогический университет \\ ул. Сретенка, 29, Москва, Россия, 127051 \\ ${ }^{3}$ Национальный исследовательский университет «Высшая школа экономики» \\ ул. Мясницкая, 20, Москва, Россия, 101000
}

В статье представлены результаты эмпирического исследования, проведенного в целях анализа различий в жизненных и семейных ценностях, а также в их взаимосвязи, между супругами из межкультурных и монокультурных семей. Выборка исследования составила 330 человек, включая 85 межкультурных русско-арабских пар (170 человек), проживающих в России, а также 80 монокультурных пар (160 человек).

В исследовании использовались следующие методики «Ценностный опросник» Ш. Шварца, «Тест установок к семейной жизни» (Ю. Алешина, Л. Гозман, Е. Дубовская), опросник «Ролевые ожидания и притязания в браке» (А. Волкова), «Удовлетворенность браком» (В. Столин, Т. Романова, Г. Бутенко).

Было обнаружено, что люди из межкультурных и монокультурных браков имеют разные иерархии жизненных и семейных ценностей, кроме того они по-разному воплощают свои жизненные цели в семейной сфере. В межкультурных браках супруги связывают возможности реализации своих нормативных целей с семьей, особенно с ее психотерапевтической и родительской функциями, а также с внесемейной активностью. Но в повседневной жизни им не всегда удается реализовать жизненные цели в семейной сфере, возможно из-за сложностей во взаимодействии с внешним окружением и относительной закрытости семьи, что, в свою очередь, приводит к снижению удовлетворенности браком. В представлениях супругов из межкультурных семей коллективистские ценности более связаны с семейным функционированием, а индивидуалистические ценности, такие как гедонизм и власть, воспринимаются как несовместимые с благополучным функционированием семьи.

Ключевые слова: межкультурный брак, жизненные ценности, семейные ценности, установки к семейной жизни, семейные функции, семейные роли, ожидания и притязания в браке, удовлетворенность браком

(C) Чеботарева Е.Ю, Джабер Х.М.А., 2017

\section{История статьи:}

Поступила в редакцию: 17 марта 2017

Принята к печати: 14 июня 2017

Для цитирования:

Чеботарева Е.Ю., Джабер Хасан М.А. Жизненные ценности людей, состоящих в межкультурных (арабо-русских) и монокультурных браках, и их реализация в семейной сфере // Becmник Российского университета дружбы народов. Серия: Психология и педагогика. 2017. Т. 14. № 3. C. 311-325. DOI 10.22363/2313-1683-2017-14-3-311-325 


\section{Сведения об авторах:}

Чеботарева Елена Юрьевна - кандидат психологических наук, доцент. Доцент: кафедры социальной и дифференциальной психологии Российского университета дружбы народов; кафедры детской и семейной психотерапии Московского государственного психолого-педагогического университета; магистерской программы «Системная семейная психотерапия» Национального исследовательского университета «Высшая школа экономики» (Москва, Россия). E-mail: chebotareva_eyu@rudn.university

Хасан М.А. Джабер - аспирант кафедры социальной и дифференциальной психологии Российского университета дружбы народов. E-mail: alone5544332211@mail.ru

Участие авторов: Чеботарева Е.Ю. - концепция и дизайн исследования, анализ полученных данных, написание текста; Хасан М.А. Джабер - сбор эмпирических данных. 